\section{Analysis of US budget plan confirms large cuts ahead}

Washington. President Bill Clinton's plan to balance the US federal government's budget by the year 2002 would cut real spending on non-military research and development (R\&D) programmes at the Department of Energy by 18 per cent, according to an assessment by the American Association for the Advancement of Science (AAAS) released this week. The research budget of the National Aeronautics and Space Administration would be cut by 17 per cent.

Overall spending on non-military R\&D would fall by 11.7 per cent by the end of that period, says the AAAS. Its conclusions on the Clinton budget are less severe for 2002 than those of a similar assessment the AAAS carried out last year of the congressional budget plan, which would have cut non-defence R\&D by 33 per cent. But Clinton's proposal brings spending down very sharply by the year 2000 , when it would have fallen by 18 per cent from last year's level, according to the AAAS assessment.

Over the six-year period, the Department of the Interior - whose largest research component is the US Geological Survey would be the hardest hit of the major government departments and agencies, with a real cut of 28 per cent. In contrast, the National Institutes of Health and the Environmental Protection Agency would fare best under the plan, with the research budgets of both holding stable until 2002.

"If these projections are actually realized, research in universities, federal laboratories and industry will face a potentially dire situ- ation," says $\mathrm{Al}$ Teich, director of policy at the AAAS.

The AAAS, whose detailed assessments of budget information are intended to extract information about projected science spending, says that the 1997 budget proposed by Clinton last month would increase non-defence $R \& D$ by 3.3 per cent. It would then fall by about 5 per cent or so for each of the subsequent three years, before recovering in 2001 and 2002.

But an AAAS statement points out that many analysts believe "that the increases proposed for 2001 and 2002 are unrealistic because they are contingent upon economic forecasts that are overly optimistic".

Both the Clinton and congressional plans hit research and development hard, as they assume that the government will cut taxes, maintain entitlements and balance the budget entirely by cutting back the so-called 'discretionary' spending approved each year by Congress. Teich points out that with $\mathrm{R} \& \mathrm{D}$ consuming one-seventh of all discretionary spending, it cannot escape severe cuts if the budget is balanced in this way.

Officials at NASA and the Department of Energy have already played down the significance of Clinton's future year projections, saying that they do not reflect policy judgements. But Teich warns the community against ignoring them. "You have to take them seriously - just as you had to take the Congressional budget resolution seriously - and work to ensure that they don't become a reality." Colin Macilwain

\section{Funds fall behind demand for brain research grants}

London. The growth in popularity of the Human Frontier Science Program (HFSP), which supports international scientific collaboration in research on brain functions and molecular approaches to the study of biological functions, seems to be confirmed by the fact that applications by young scientists for two-year research fellowships have increased by 19 per cent since last year.

At the same time, in announcing the details of its 1996 awards, HFSP officials say that the steady increase in the number of high-quality applications for awards over the past five years is causing concern among the trustees of the programme that many excellent applications are having to be turned down because of lack of funds.

"The increase in applications reflects the shortage of fellowships around the world," says Pierre Chambon of the Louis Pasteur University in Strasbourg, who is chairman of the HFSP's Council of Scientists, which supervises the scientific direction of its programme.

Chambon argues that the low success rate - only 10 per cent of applications for research awards, and 19 per cent of those

for fellowships,

녿 are successful adds to the pres-

IMAGE tige of the pro-

UNAVAILABLE gramme, whose FOR current budget is

COPYRIGHT US\$46 million a

REASONS year. He would like to see the size of contributions to the programme increased; at present, about 80 per

cent of the pro-

Chambon: shortage

authority between the federal government and the provinces, and that the federal government is free to select what it wishes to investigate.

The federal government has itself already challenged Krever's right to issue the 'potential wrongdoing' notices. In this it was joined by provincial governments, private organizations and individuals. But Quebec's latest move is much more far-reaching than such earlier efforts to muzzle the inquiry, as it could limit the federal government's broad involvement in setting standards in areas such as health care.

The executive director of the Quebec branch of the Canadian Hemophilia Association, reacted to the province's claim about the unconstitutionality of Krever's action by saying those infected by tainted blood are beginning to despair, as they are coming to believe that governments do not want to know the truth about the blood tragedy.

David Spurgeon fellowships worldwide. gramme's income comes from Japan, while
Europe and the United States each conEurope and the United
tribute about 10 per cent.

Forty-five research grants have been awarded in the current funding round, 14 in brain research and 31 in molecular studies. An important feature of the programme is that each grant is awarded to at least two teams from different countries. Among the 45 grants, 39 have at least one scientist working in the United States and 27 have at least one scientist working in Japan.

Responding to the needs of the international neuroscience community, HFSP has launched a programme of workshops on topical scientific issues in brain function and biological function at the molecular level. The first of these, "Coincidence Detection in the Nervous System", was held in Strasbourg in 1995. The proceedings form the first publication in a series aimed at specialists, postdocs and students. Ruth Bell 